\title{
PLATELETS AND THE CLINICAL COURSE OF CROHN'S DISEASE
}

\section{PŁYTKI KRWI A PRZEBIEG KLINICZNY CHOROBY LEŚNIOWSKIEGO-CROHNA}

\author{
Milena Padysz ${ }^{1(A, B, C, D, E, F, G)}$, Krystyna Stec-Michalska $^{1(A, D, E, F, G)}$, \\ Julia Banasik $^{1(\mathrm{~B})}$, Anita Gąsiorowska ${ }^{1(\mathrm{E}, \mathrm{F})}$
}

${ }^{1}$ Department of Gastroenterology, Medical University of Lodz, Poland

Authors' contribution Wkład autorów: A. Study design/planning zaplanowanie badań B. Data collection/entry zebranie danych C. Data analysis/statistics dane - analiza i statystyki D. Data interpretation interpretacja danych E. Preparation of manuscript przygotowanie artykułu F. Literature analysis/search wyszukiwanie i analiza literatury G. Funds collection zebranie funduszy
Tables: 6

Figures: 2

References: 25

Submitted: 2017 May 18

Accepted: 2017 Jul 12

\section{Summary}

Background. Crohn's disease (CD) is a chronic, autoimmune, inflammatory bowel disease (IBD) characterised by periods of exacerbations and remissions. Autoimmune disorders caused by undetermined factors lead to inflammation in the intestinal mucosa. Presently, there is a growing interest in the role of platelets in the assessment of inflammatory lesions in CD. Accordingly, the aim of this study was to answer the question of whether routinely measured platelet indices: concentration of platelets (PLT), the mean platelet volume (MPV), plateletcrit (PCT) could become biomarkers for monitoring the course of CD.

Material and methods. In the study programme, there were enrolled 100 patients with a diagnosed CD with a different clinical course, disease location and heterogeneous therapy. In all patients, there were collected blood and stool samples for the assessment of CRP, blood count and fecal calprotectin evaluation. The clinical state of each patient was classified using the Harvey-Bradshaw index.

Results. The study showed a positive, statistically significant correlation between fecal calprotectin, CRP, WBC, the Harvey-Bradshaw index and the number of platelets and PCT. Furthermore, the analysis showed a statistically significant negative correlation between MPV and the number of WBC, CRP and fecal calprotectin.

Conclusions. Our study showed that platelet indices are a valuable, non-invasive and widely accessible method to assess mucosal healing and the clinical status of the patient.

Keywords: Crohn disease, inflammatory bowel disease, platelets, mean platelet volume

\section{Streszczenie}

Wprowadzenie. Choroba Leśniowskiego-Crohna (CD) należy do przewlekłych nieswoistych chorób zapalnych jelit (IBD) o podłożu autoimmunologicznym, przebiegająca z okresami zaostrzeń i remisji. U jej podstaw leżą zaburzenia autoimmunologiczne wywołane przez nieokreślone czynniki, prowadzące do zmian zapalnych w błonie śluzowej jelita. Rośnie zainteresowanie płytkami krwi w aspekcie oceny stanu zaawansowania zmian zapalnych w CD. Celem pracy była odpowiedź na pytanie, czy rutynowo oznaczane w morfologii krwi parametry płytkowe: ilość płytek krwi (PLT), średnia objętość płytek krwi (MPV), płytkokryt (PCT) mogą być wskaźnikami służącymi do monitorowania przebiegu CD.

Materiał i metody. Do badań zakwalifikowano 100 pacjentów o zróżnicowanym przebiegu klinicznym, lokalizacji zmian i stosowanej terapii. U wszystkich chorych pobrano krew oraz próbki do stolca celem oznaczenia CRP, morfologii krwi oraz kalprotektyny w kale. Stan kliniczny każdego pacjenta oceniano wykorzystując wskaźnik Harvey- Bradshaw.

Wyniki. Wykazano istotnie statystyczną dodatnią korelacje pomiędzy kalprotektyną, CRP, WBC, wskaźnikiem Harvey-Bradshaw oraz ilościa płytek krwi i płytkokrytem. Analiza wykazała także istotnie statystyczną ujemną korelację pomiędzy MPV i ilością WBC, CRP oraz kalprotektyną.

Wnioski. W naszym badaniu wykazano, że parametry płytkowe mogą stanowić użyteczną, nieinwazyjną i powszechnie dostępną metodę, służącą do oceny gojenia śluzówkowego i stanu klinicznego pacjenta z CD.

Słowa kluczowe: choroba Leśniowskiego-Crohna, nieswoiste zapalenie jelit, płytki krwi, MPV 


\section{Introduction}

Crohn's disease (CD) is a chronic inflammatory autoimmune bowel disease (IBD), with periods of exacerbation and remission. The etiopathogenesis of the disease is complex and not fully understood. Its underlying autoimmune disorders are caused by undetermined factors leading to inflammatory processes in the intestinal mucosa. They are accompanied by abnormal blood clotting, there is a mutual interaction that triggers the mechanism of a vicious circle [1]. The key link between these processes are platelets (PLT) [2]. Hence, the question of whether the parameters of the platelets marked with standard blood count could be used as a non-invasive marker to monitor the severity of inflammation in CD. In the blood count, we can measure concentration of PLT (standard 150-400 thousand/ $\mu \mathrm{l}$ ), the mean platelet volume MPV (standard 7-12 fl, plateletcrit PCT-platelet volume ratio to the total (standard 0.14-0.36\%), P-LCR- percentage of platelet large cell ratio over $20 \mathrm{fl}$ (standard 0.2-5\%), as well as the rate of variation in the volume of blood platelets, which reflects the anisocytosis PDW-platelet distribution width (reference values 6.1-11 fl PDW\% 40-60\%) [3].

The most commonly designated biomarkers of inflammation in $\mathrm{CD}$ are $\mathrm{C}$ - reactive protein CRP, the concentration of white blood cells (WBC) and, recently, calprotectin in feces, regarded as the most reliable marker to monitor mucosal healing [4]. Calprotectin is secreted into the extracellular space under the influence of proinflammatory cytokines released by neutrophils or monocytes. This protein has pro-apoptotic and bactericidal activity by the ability to bind calcium and zinc ions [5]. The value of $<100 \mu \mathrm{g} / \mathrm{g}$ of feces is considered the norm. Its concentration in feces below $150 \mu \mathrm{g} / \mathrm{g}$ of stool is considered as the cut-off point of mucosal healing in IBD [6]. Calprotectin in feces is not degraded by the microflora, as it is stable and resistant to proteolysis for about seven days at room temperature and at $20^{\circ} \mathrm{C}$ to approx. 3 months [7]. The aim of this study was to answer the question of whether routinely measured indices in the blood count of PLT, MPV, PCT could be used in everyday clinical practice to monitor the course of CD on the basis of an analysis of their correlation between CRP, WBC and calprotectin in feces in terms of clinical and endoscopic remission.

\section{Material and methods}

In the study programme there were enrolled 100 patients with $\mathrm{CD}, \mathrm{W}: 50 / \mathrm{M}: 50$ at the age of $(33.5 \pm 11)$ treated in the Department of Gastroenterology and Outpatient Clinic in Medical University of Lodz, with a different clinical course, localisation of lesions and heterogeneous therapy (Table 1).

Table 1. Characteristics of the study group patients with CD

\begin{tabular}{|c|c|}
\hline Parameter & \\
\hline Gender (Women:Men) & $50: 50$ \\
\hline Age (years) & $\begin{array}{c}\text { range } 19-62 \\
\text { average } 33.5 \pm 11\end{array}$ \\
\hline $\begin{array}{c}\text { Localisation of intestinal lesions } \\
\text { L1- ileum } \\
\text { L2- colon } \\
\text { L3- ileum + colon } \\
\text { L3+L4- L3 + upper gastrointestinal tract }\end{array}$ & $\begin{array}{cc}\mathrm{n}=20 & \mathrm{~W}: 11 / \mathrm{M}: 9 \\
\mathrm{n}=25 & \mathrm{~W}: 12 / \mathrm{M}: 13 \\
\mathrm{n}=51 & \mathrm{~W}: 25 / \mathrm{M}: 26 \\
\mathrm{n}=4 & \mathrm{~W}: 2 / \mathrm{M}: 2\end{array}$ \\
\hline
\end{tabular}

The diagnosis of CD was determined basing on the criteria of European Crohn's and Colitis Organisation ECCO [8]. The criteria of exclusion included the lack of informed consent of the patient to participate in the study, age under 18 years and the presence of other chronic diseases. Initially, the clinical condition of each patient was evaluated using the most widely used Harvey-Bradshaw (H-B) index, the simplified scale of CDAI (Crohn's Disease Activity Index) [9]. H-B index takes into account 5 parameters of the day before the visit: general wellbeing, severity of abdominal pain, the number of liquid stools, abdominal mass, and associated complications. Remission is defined as $<5$ points, mild disease 5-7 pts, moderate disease 8-16 pts, severe disease $>16$ pts. This index correlates well with the results of the CDAI scale [10].

To determine the complete blood count and necessary biochemical parameters in serum, $2 \mathrm{~mL}$ of venous blood was collected from all patients to standard tubes containing EDTA. WBC, PLT, MPV, PCT, CRP were routinely marked (no later than 2 hours after collection). The concentration of calprotectin in feces was determined using quantitative immunochromatographic tests (QUANTUM BLUE), calibrated in the range of 100 to $1,800 \mu \mathrm{g} / \mathrm{g}$ (Table 2). The feces samples were stored at $-20^{\circ} \mathrm{C}$. 
Table 2. Mean values of platelet indices, CRP, WBC and calprotectin in the whole study group

\begin{tabular}{|c|c|c|c|c|c|c|}
\hline & \multicolumn{3}{|c|}{ Platelet indices } & \multirow{2}{*}{ CRP } & \multirow{2}{*}{ WBC } & \multirow{2}{*}{ Calprotectin } \\
\cline { 2 - 5 } & PLT & MPV & PCT & & & \\
\hline $\begin{array}{c}\text { average } \pm \\
\text { standard } \\
\text { deviation }\end{array}$ & $319.42 \pm 151.7$ & $10.39 \pm 1.25$ & $0.33 \pm 0.13$ & $26.55 \pm 41.68$ & $6.96 \pm 2.75$ & $777.46 \pm 659.62$ \\
\hline
\end{tabular}

Abbreviations: PLT- platelets; MPV-mean platelet volume; PCT- plateletcrit; CRP- C reactive protein; WBC-white blood cells

\section{Statistical analysis}

The results were statistically analysed using Statistica software and Excel. The statistical analysis was performed using the Spearman's rank test and Mann-Whitney $U$ test. In all analyses, the significance level was set at $\mathrm{p}=0.05$.

\section{Ethics}

The study was approved by the Bioethical Committee of the Medical University of Lodz.

\section{Results}

Eligible patients are characterised by age, gender and localisation of inflammatory lesions in the intestine and clinical status of CD advancement, calculating the ratio of $\mathrm{H}-\mathrm{B}$. The collected data are shown in Table 1 and Table 5 .

Then, the mutual correlation between the platelet parameters: PLT, MPV, PCT and CRP, WBC, calprotectin was rated (Table 3 ).

Table 3. Correlation between the platelet parameters and inflammatory markers (CRP, WBC, calprotectin)

\begin{tabular}{|c|c|c|c|c|c|c|}
\hline \multirow{2}{*}{} & \multicolumn{2}{|c|}{ PLT } & \multicolumn{2}{c|}{ MPV } & \multicolumn{2}{c|}{ PCT } \\
\cline { 2 - 7 } & $\mathbf{R}$ & $\mathbf{p}$ & $\mathbf{R}$ & $\mathbf{p}$ & $\mathbf{R}$ \\
\hline \multirow{2}{*}{ Calprotectin } & 0.427180 & 0.000009 & -0.365616 & 0.000269 & 0.383067 & 0.000127 \\
\hline CRP & 0.486171 & 0.000000 & -0.337453 & 0.000825 & 0.458504 & 0.000003 \\
\hline WBC & 0.486070 & 0.000000 & -0.206445 & 0.044727 & 0.499170 & 0.000000 \\
\hline
\end{tabular}

Abbreviations: PLT- platelets; MPV-mean platelet volume; PCT- plateletcrit; CRP- C reactive protein; WBC-white blood cells

It indicated a statistically significant positive correlation between calprotectin, CRP and leukocytosis, and the concentration of PLT and PCT $(\mathrm{p}<0.05)$.

With an increase of inflammatory parameters in patients with CD (CRP, leukocytosis, fecal calprotectin) a significant increase is visible in serum concentrations of the PLT and PCT indices.

The graphical relationship between the concentration of calprotectin in feces and the concentration of PLT is shown in Figure 1.

It was decided to present graphically only the correlation between fecal and platelet parameters because it is of the highest diagnostic value in the assessment of mucosal healing in CD.

There was a negative correlation between MPV and CRP, WBC and calprotectin (Table 3), which might indicate that, with the increase of inflammatory parameters, MPV is decreased $(\mathrm{p}<0.05)$.

Another parameter subjected to analysis was the H-B index in correlation with platelet parameters and calprotectin. There was a significant statistical correlation between $\mathrm{H}-\mathrm{B}$ index and the number of platelets ( $\mathrm{p}$ $<0.05 ; \mathrm{r}=0.37)$ and PCT $(\mathrm{p}<0.05 ; \mathrm{r}=0.32)$. In addition, there was a positive correlation between the H-B index and the concentration of calprotectin in feces $(\mathrm{p}<0.0001, \mathrm{r}=0.41)$. In MPV, no significant relationship between the H-B index and calprotectin was observed, although there was noted an inversely proportional trend (Table 4). 


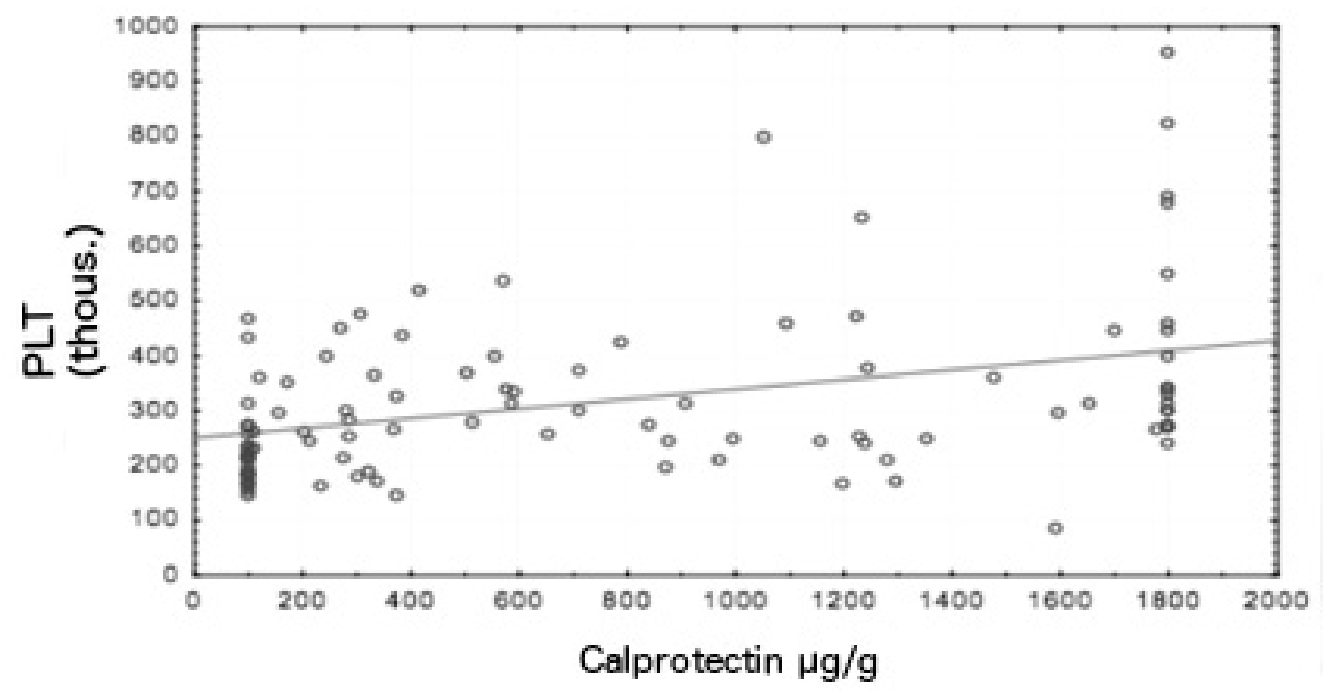

Figure 1. The correlation between the number of platelets (PLT) and the concentration of calprotectin in faeces of patients with CD

Table 4. Harvey-Bradshaw index correlation with platelet parameters and calprotectin

\begin{tabular}{|c|c|c|}
\hline \multirow{2}{*}{ PLT } & R & Harvey-Bradshaw index \\
\cline { 2 - 3 } & 0.375609 & 0.000118 \\
\hline MPV & -1.152324 & 0.140580 \\
\hline PCT & 0.319018 & 0.001627 \\
\hline Calprotectin & 0.414463 & 0.000018 \\
\hline
\end{tabular}

Abbreviations: PLT- platelets; MPV-mean platelet volume; PCT- plateletcrit

From a clinical point of view, there is an interesting relationship between platelet parameters and the clinical and mucosal severity of CD. Thus, there was analysed the relationship between the concentration of calprotectin in feces, platelet parameters in patients in clinical remission ( $\mathrm{H}-\mathrm{B}$ index $<5 \mathrm{pts}$ ) and in the period of exacerbation (H-B index -5-16 pts). Among the enrolled patients there were selected: 31 persons during clinical remission and 69 during clinical exacerbation of the disease. In patients with clinical exacerbation of CD (H-B ratio greater than 5 pts), there are significantly higher values of calprotectin, PLT, PCT $(p<0.05)$, with no statistical significance in relation to the MPV (Table 5).

Table 5. Comparison of average values of calprotectin in feces and platelet parameters in patients in clinical remission (H-B index $<5$ points) and in the period of exacerbation (H-B index $-5-16$ points)

\begin{tabular}{|c|c|c|c|}
\hline & $\begin{array}{c}\text { H-B index }<\mathbf{5} \text { points. } \mathbf{n}=\mathbf{3 1} \\
\text { average } \pm \text { standard devi- } \\
\text { ation }\end{array}$ & $\begin{array}{c}\text { H-B index 5-16 points } \\
\mathbf{n = 6 9} \\
\text { average } \pm \text { standard devi- } \\
\text { ation }\end{array}$ & $\mathbf{p}$ \\
\hline Calprotectin & $481.3 \pm 512.5$ & $910.5 \pm 678.0$ & 0.019 \\
\hline PLT & $259.7 \pm 106.6$ & $346.2 \pm 161.7$ & 0.0008 \\
\hline MPV & $10.5 \pm 1.1$ & $10.4 \pm 1.3$ & 0.4424 \\
\hline PCT & $0.27 \pm 0.10$ & $0.35 \pm 0.13$ & 0.0064 \\
\hline
\end{tabular}

Abbreviations: PLT- platelets; MPV-mean platelet volume; PCT- plateletcrit

Then, the obtained results were analysed for their suitability assessment of blood platelet parameters in the context of mucosal healing taking into account the concentration of calprotectin in feces. The examined patients were divided into two groups: 26 patients in remission (concentration of calprotectin in the feces $\leq 150 \mu \mathrm{g} / \mathrm{g}$ ) and 74 patients with active inflammatory lesions in the intestinal wall (calprotectin in the feces $>150 \mu \mathrm{g} / \mathrm{g}$ ), irrespective of disease activity in the H-B scale. The obtained results are shown in Table 6. 
Table 6. Comparison of average values of platelet parameters in patients in remission (concentration of calprotectin in the feces $\leq 150 \mu \mathrm{g} / \mathrm{g}$ ) and in patients with active disease (calprotectin in the feces $>150 \mu \mathrm{g} / \mathrm{g}$ )

\begin{tabular}{|c|c|c|c|}
\hline & \multicolumn{2}{|c|}{ The concentration of calprotectin } & \multirow[b]{2}{*}{$\mathbf{p}$} \\
\hline & $\begin{array}{c}\leq 150 \mathrm{ug} / \mathrm{g} \\
\mathrm{n}=26 \\
\text { average } \pm \text { standard } \\
\text { deviation }\end{array}$ & $\begin{array}{c}>150 \mathrm{ug} / \mathrm{g} \\
\mathrm{n}=74 \\
\text { average } \pm \text { standard } \\
\text { deviation }\end{array}$ & \\
\hline PLT & $237.0 \pm 80.1$ & $348.4 \pm 160.5$ & 0.0000 \\
\hline MPV & $10.9 \pm 1.1$ & $10.2 \pm 1.3$ & 0.0051 \\
\hline PCT & $0.26 \pm 0.09$ & $0.35 \pm 0.13$ & 0.0001 \\
\hline
\end{tabular}

Abbreviations: PLT- platelets; MPV-mean platelet volume; PCT- plateletcrit

Average values of PLT and PCT are significantly statistically higher $(\mathrm{p}<0.05)$ in patients with active mucosal lesions compared to those in remission (calprotectin $<150 \mu \mathrm{g} / \mathrm{g}$ of fecal), while platelet volume is significantly decreased - MPV $(\mathrm{p}<0.05)$.

This means that a comparative analysis of the concentration of PLT, MPV and PCT in patients with CD from routinely carried out complete blood cell count provide valuable information relating to inflammatory lesions in the intestinal wall.

\section{Discussion}

Intensive research on the participation of PLT in inflammatory processes and its impact on the immune system is being carried out [11]. PLT secrete proteins directly combating bacteria called PMP (platelet microbicidal proteins) and active forms of oxygen. Releasing chemokines affect the anti-inflammatory activity of leukocytes [12].

Besides, it is now known that the severity of inflammation in IBD is accompanied by an increase in the concentration of PLT and morphology disorders [2]. The earliest observations were made already in 1968, when the presence of thrombocytosis in the active phase of IBD was documented [13]. Subsequent reports confirmed a positive correlation between the clinical activity of the disease and the number of blood platelets [14]. Our study confirmed a positive correlation between the number of platelets in the serum and the severity of the clinical condition (index H-B) (Table 4) and the healing of the mucous membranes on the basis of the concentration of calprotectin in feces (Tables 3, 5). Some researchers propose using thrombocytosis in the differential diagnosis of IBD and infectious diarrhea [15].

The IBD platelets circulate in the state of excessive activity; they tend to aggregate due to coagulation factors. During in vitro studies in patients with IBD, there was noticed a trend for spontaneous activation of PLT in more than $30 \%$, regardless of the severity of the disease [16]. It is believed that excessive activation of thrombocytes is a specific feature of IBD [17]. Selective P-glycoprotein (platelet-leukocyte aggregates) belonging to adhesion molecules is expressed on activated platelets and stimulates the formation of aggregates of platelets and leukocytes. It has been shown that it significantly increases the concentration of PLAs in patients with IBD. Accordingly, there is a beneficial effect of azathioprine's used in the treatment of IBD, as it lowers the PLAs inhibiting the phosphorylation of adenosine [18].

Most interest in the determined parameters of blood platelets was aroused by MPV $[19,20]$. The released inflammatory mediators stimulate the bone marrow to produce more PLT at the expense of its maturation time, as there are released fewer platelets. At the same time, more and more active PLT are consumed in inflammation.

In our study, patients with CD revealed that the higher the concentration of calprotectin and CRP, the significantly lower MPV ( $p<0.05$ ) (Table 3, Figure 2).

We have obtained interesting data in the comparative analysis of MPV value in patients with the concentration of calprotectin in feces above and below $150 \mu \mathrm{g} / \mathrm{g}$ of the feces. The value of MPV in patients with severe mucosal lesions is lower than in those in the period of mucosa remission $(p<0.05)$ (Table 6). There are reports suggesting that the decline in the value of MPV in CD may be a useful marker for predicting the loss of response to infliximab therapy [21]. Hence, MPV monitoring could affect the treatment modification. The more so that the present study showed no significant correlation between MPV and the clinical activity of the disease by the Harvey Bradshaw index (Tables 4, 5). 


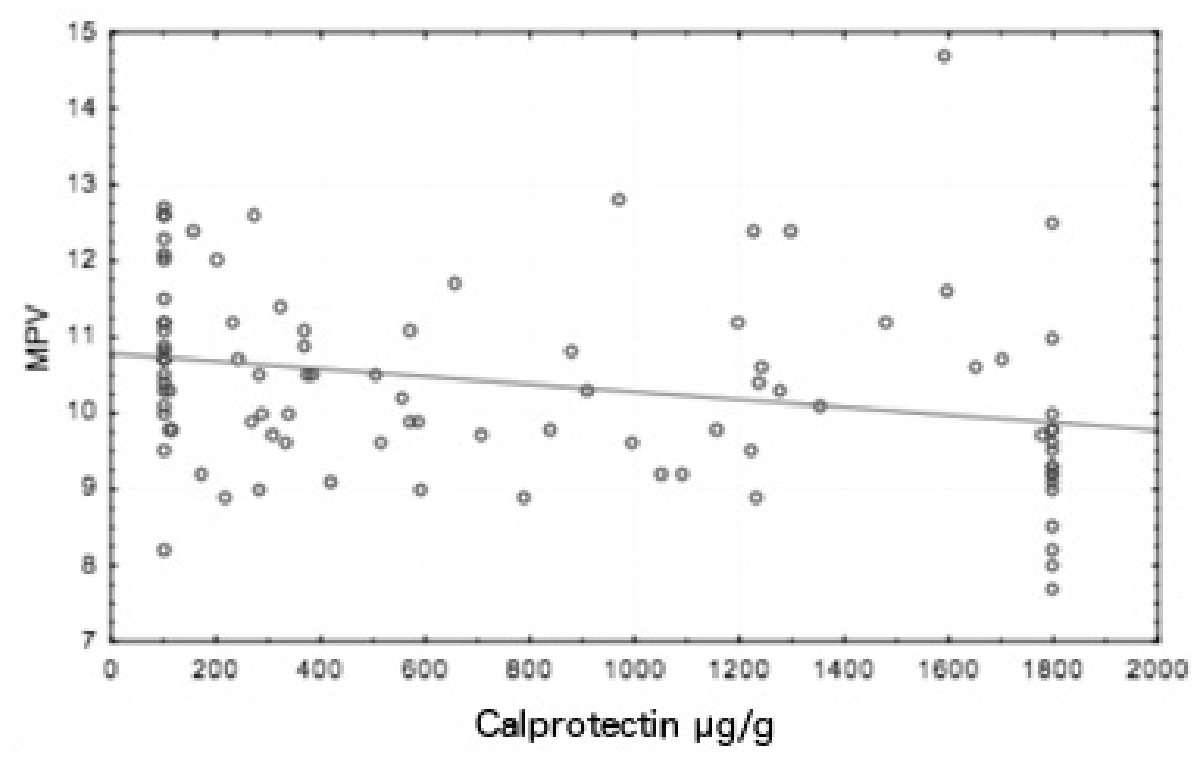

Figure 2. Graph showing the correlation between the values of MPV and the concentration of calprotectin in the faeces of patients with CD.

Some reports identified an increased expression in active platelets of CD40 ligand protein, which plays a key role in the release of pro-inflammatory cytokines [22]. The increased expression was found in biopsies taken at the inflamed mucosa of the ileum or colon of patients with CD and colitis ulcerosa [23, 24]. Therefore, it has been suggested that these patients are administered low molecular weight heparin during exacerbation requiring hospitalisation [25].

The increase in the total volume of the platelet in inflammation reflects PCT. In our study, we have shown a positive correlation between the growth parameters of inflammation (calprotectin, CRP, WBC) and PCT (Table 3). Moreover, we have observed a similar relationship with regard to the clinical condition of the patients.

\section{Conclusions}

The analysis of the platelet parameters contained in the blood counts routinely performed in patients with CD could become a valuable non-invasive, inexpensive and widely accessible method to assess mucosal healing and the clinical status of the patient.

The observed increase in PLT, PCT and MPV reduction can be helpful in decision-making used to expand laboratory diagnostics and imaging, and thus optimising the therapy. There is a further need for research into the role of platelets in the pathogenesis of CD conducted on a large population of patients.

\section{Acknowledgements}

This work was supported by a grant No. 502-03 / 5-006-02 / 502-54-074 from Medical University of Lodz.

\section{References:}

1. Yoshida H, Granger DN. Inflammatory bowel disease: a paradigm for the link between coagulation and inflammation. Inflammatory Bowel Diseases. 2009; 15(8): 1245-1255. https://doi.org/10.1002/ibd.20896

2. Voudoukis E, Karmiris K, Koutroubakis IE. Multipotent role of platelets in inflammatory bowel diseases: a clinical approach. World Journal of Gastroenterology: WJG. 2014; 20(12): 3180-3190.

https://doi.org/10.3748/wjg.v20.i12.3180

3. Dembińska-Kieć A, Naskalski J. Diagnostyka laboratoryjna z elementami biochemii klinicznej. Podręcznik dla studentów medycyny. Wrocław: Elsevier Urban \& Partner; 2009 (in Polish).

4. Sipponen, T, Kolho KL. Fecal calprotectin in diagnosis and clinical assessment of inflammatory bowel disease. Scandinavian Journal of Gastroenterology. 2015; 50(1): 74-80.

https://doi.org/10.3109/00365521.2014.987809 
5. Yui S, Nakatani Y, Mikami M. Calprotectin (S100A8/S100A9), an inflammatory protein complex from neutrophils with a broad apoptosis-inducing activity. Biological \& Pharmaceutical Bulletin. 2003; 26(6): 753-760. https://doi.org/10.1248/bpb.26.753

6. Walsham NE, Sherwood RA. Fecal calprotectin in inflammatory bowel disease. Clinical and Experimental Gastroenterology. 2016; 9: 21-29.

7. Eder P, Stawczyk-Eder K, Krela-Kaźmierczak I, Linke K. Przydatność oznaczania kalprotektyny w stolcu w chorobie Leśniowskiego i Crohna. Polskie Archiwum Medycyny Wewnętrznej. 2008; 118(11): 1-4 (in Polish).

8. Dignass A, Assche GV, Lindsay JO, Lémann M, Söderholm J, Colombel JF, et al. The second European evidencebased Consensus on the diagnosis and management of Crohn's disease: current management. Journal of Crohn's and Colitis. 2010; 4(1): 28-62. https://doi.org/10.1016/j.crohns.2009.12.002

9. Harvey RF, Bradshaw JM. A simple index of Crohn's-disease activity. Lancet (London, England). 1980; 1(8167): 514. https://doi.org/10.1016/S0140-6736(80)92767-1

10. Vermeire S, Schreiber S, Sandborn WJ, Dubois C, Rutgeerts P. Correlation between the Crohn's disease activity and Harvey-Bradshaw indices in assessing Crohn's disease severity. Clinical Gastroenterology and Hepatology. 2010; 8(4): 357-363. https://doi.org/10.1016/j.cgh.2010.01.001

11. Öztürk ZA, Dag MS, Kuyumcu ME, Cam H, Yesil Y, Yilmaz N, et al. Could platelet indices be new biomarkers for inflammatory bowel diseases? European Review for Medical and Pharmacological Sciences. 2013; 17: 334-341.

12. Smorąg, I, Baj Z. Nonhemostatic role of platelets. Diagnostyka Laboratoryjna. 2008; 44: 241-248.

13. Morowitz DA, Allen LW, Kirsner JB. Thrombocytosis in chronic inflammatory bowel disease. Annals of Internal Medicine. 1968; 68(5): 1013-1021. https://doi.org/10.7326/0003-4819-68-5-1013

14. Harries AD, Fitzsimons E, Fifield R, Dew MJ, Rhoades J. Platelet count: a simple measure of activity in Crohn's disease. British Medical Journal (Clinical Research Ed.). 1983; 286(6376): 1476. https://doi.org/10.1136/bmj.286.6376.1476

15. Harries AD, Beeching NJ, Rogerson SJ, Nye FJ. The platelet count as a simple measure to distinguish inflammatory bowel disease from infective diarrhea. The Journal of Infection. 1991; 22(3): 247-250. https://doi.org/10.1016/S0163-4453(05)80006-4

16. Collins CE, Cahill MR, Newland AC, Rampton DS. Platelets circulate in an activated state in inflammatory bowel disease. Gastroenterology. 1994; 106(4): 840-845. https://doi.org/10.1016/0016-5085(94)90741-2

17. Giannotta M, Tapete G, Emmi G, Silvestri E, Milla M. Thrombosis in inflammatory bowel diseases: what's the link? Thrombosis Journal. 2015; 13(1): 14. https://doi.org/10.1186/s12959-015-0044-2

18. Wazna E. Platelet-mediated regulation of immunity. Postępy Higieny i Medycyny Doświadczalnej. 2006; 60: 265-277.

19. Yuri Gasparyan A, Ayvazyan L, Mikhailidis DP, Kitas DG. Mean platelet volume: a link between thrombosis and inflammation? Current Pharmaceutical Design. 2011; 17(1), 47-58. https://doi.org/10.2174/138161211795049804

20. Kapsoritakis AN, Koukourakis MI, Sfiridaki A, Potamianos SP, Kosmadaki MG, Koutroubakis IE, et. al. Mean platelet volume: a useful marker of inflammatory bowel disease activity. The American Journal of Gastroenterology. 2001; 96(3): 776-781. https://doi.org/10.1111/j.1572-0241.2001.03621.x

21. Sobolewska A, Włodarczyk M, Stec-Michalska K, Fichna J, Wiśniewska-Jarosińska M. Mean platelet volume in Crohn's disease patients predicts sustained response to a 52-week Infliximab therapy: a pilot study. Digestive Diseases and Sciences. 2016; 61(2): 542-549. https://doi.org/10.1007/s10620-015-3894-3

22. Matowicka-Karna J. Markery zapalenia, aktywacja płytek krwi i zaburzenia krzepnięcia w chorobach zapalnych jelit. Postępy Higieny i Medycyny Doświadczalnej. 2016; 70: 305-312 (in Polish). https://doi.org/10.5604/17322693.1199305

23. Borcherding F, Nitschke M, Hundorfean G, Rupp J, Smolinski von D, Bieber K, et al. The CD40-CD40L Pathway contributes to the proinflammatory function of intestinal epithelial cells in inflammatory bowel disease. The American Journal of Pathology. 2010; 176(4): 1816-1827. https://doi.org/10.2353/ajpath.2010.090461

24. Collins CE, Rampton DS, Rogers J, Williams NS. Platelet aggregation and neutrophil sequestration in the mesenteric circulation in inflammatory bowel disease. European Journal of Gastroenterology \& Hepatology. 1997; 9(12): 1213-1217.

25. Magro F, Soares JB, Fernandes D. Venous thrombosis and prothrombotic factors in inflammatory bowel disease. World Journal of Gastroenterology. 2014; 20(17): 4857-4872.

https://doi.org/10.3748/wjg.v20.i17.4857 